\title{
IMPACT OF FINANCIAL LITERACY (FL) AND ACCESS TO BANKING SERVICES (AC) ON FINANCIAL WELL-BEING (FWB): AN EMPIRICAL STUDY
}

\author{
Dr. Jitender Kumar \\ Assistant Professor, Department of Management Studies, Deenbandhu Chhotu Ram \\ University of Science and Technology, Murthal, Sonepat, Haryana, India
}

\section{Garima Bansal}

Research Scholar, Department of Management Studies, Deenbandhu Chhotu Ram University of Science and Technology, Murthal, Sonepat, Haryana, India

\begin{abstract}
This paper aims to examine the mediating role of $A C$ between the financial literacy (FL) level and financial wellbeing (FWB) of select individuals residing in National Capital Region of India. The sample study considers 476 conveniently selected individuals. The authors' suggest that FL helps in enhancing financial knowledge and in developing skills of individuals so that they can compare and choose best finance oriented products and services which ultimately increase access to banking services. Thus, results demonstrate that without AC, FL alone can't enhance the level of FWB among individuals residing in National Capital Region of India. No doubt, prior studies have explored association between FL and FWB; however, the mediating role of $A C$ within this domain has remained unexplored. Findings will enable Governments and policymakers to target vulnerable groups and design financial strategies and policies to increase their FL level which increases their access to banking services which ultimately help in advancing the level of FWB. The study ignores the qualitative study through interviews. Further study focuses only on one dimensions of financial inclusion, thus ignoring other dimensions.
\end{abstract}

Key words: Financial Knowledge, Financial Inclusion, Financial Access, Mediating role, Financial Well-being.

Cite this Article: Jitender Kumar and Garima Bansal, Impact of Financial Literacy (FL) and Access to Banking Services (AC) on Financial Well-being (FWB): An Empirical Study, International Journal of Management, 11(12), 2020, pp. 1010-1020. http://iaeme.com/Home/issue/IJM?Volume $=11 \&$ Issue $=12$ 
Impact of Financial Literacy (FL) and Access to Banking Services (AC) on Financial Well-being (FWB): An Empirical Study

\section{INTRODUCTION}

In this complex and sophisticated financial environment, financial literacy has been considered as an imperative skill for individuals. Financial literacy (FL) helps individual for making good financial planning and in understanding risk-return characteristics of complex finance related products and services available in market. It enables them in assessing and understanding financial services and making better financial decisions. It promotes consumers participation in the banking and credit system that is beneficial to their financial well-being (Braunstein and Welch, 2002). It helps people in making better financial choices, in knowing why long term investments are better and in knowing about financial services. This will improve overall growth of the country and the life of poor people (Damodaran, 2013).

However, various international and Indian studies indicate low FL level among individuals and recommend that measures are required to overcome this problem. In financial decisions area, it is imperative to understand how individuals' FL affects individuals' access to banking services (AC) like savings, affordability of financial services, etc. Previous studies like Caskey (2006), and Chakravarty and Pal (2013) show that how AC influences individuals' wellbeing. The studies observe that developing countries are facing finance gap and inadequate AC. Thus, for the long term growth, countries are focusing on financial access and financial wellbeing (FWB) of individuals. However, despite various innovations in the arena of finance and technology for promoting financial literacy and increasing the access to finance oriented products \& services provided by banks, individuals are not well developed.

The observations of the studies suggest that AC has remained unexplored which contributes to FWB of individuals. The present study will help government and policymakers in framing national strategies and designing policies suitable for groups who lack financial literacy and access to banking services. It is assumed these contributions vindicate this study.

\section{CONCEPTUAL FRAMEWORK}

\subsection{Financial literacy concept}

Potrich et al. (2016) consider financial literacy an imperative element for financial growth, development and stability. Remund (2010) study highlights two aspects of financial literacy i.e. comprehension of fundamental financial concepts and possession of confidence to manage personal finances. Financial literacy concept has got attention in recent years, still complex phenomena. In the view of Angela et al. (2009), "financial literacy is knowledge of basic economic and financial concepts, as well as the ability to use that knowledge and other financial skills to manage financial resources effectively for a life time well-being". Organization for Economic Co-operation and Development (OECD), 2013 defined, "financial literacy is a combination of awareness, skill, attitude, knowledge and behaviour necessary to make sound financial decisions and ultimately achieve individual financial well-being".

\subsection{Financial literacy (FL) and access to banking services (AC)}

Recent studies like (Allen et al. 2016) reveal that financial inclusion results in more financial depth, availability of financial accounts at low cost or accessibility of financial institutions. Lusardi (2002) study shows financial literacy as an important determinant of savings behaviour. Poor people don't save as they lack financial literacy. Savings provide protection against financial shocks. Therefore, the government should promote financial literacy. Cohen and Nelson (2011) argue that financial literacy acts a key accelerator in attaining the goal of financial inclusion. It tackles the imbalances caused by information asymmetry and institutional abuses, integrates financial knowledge, develops skills and promotes attitude that helps in comparing and choosing financial products \& services and ultimately purchasing and 
using the best ones. Ghosh and Vinod (2017) investigate factors that hinder to understand and use of finance among women in India and reveal as education level improves people access more from formal institutions and borrow less from informal sources. The review thus summarizes following hypothesis:

$$
\mathrm{H}_{1} \text { : FL significantly affects AC among select individuals in NCR (India). }
$$

\subsection{Financial literacy (FL) and financial well-being (FWB)}

Hogarth (2006) view financial literacy as one important step for financial well-being. The study highlights association between financial well-being and financial education and show that financial literacy prevents people from getting into financial crisis, provides information about the risk \& return characteristics of finance oriented products \& services and makes changes in consumers' attitudes \& behaviours. Widdowson and Hailwood (2007) also explain that good financial literacy level can results in effective management of budget, prudent investment, planned debt level, a better understanding of sophisticated finance oriented products and services, improved financial wealth, better risk-return decisions and enhanced standard of living. Nye and Hillyard (2013) also confirm that consumers who are literate financially, they are able to make progressive financial decisions and will experience a great sense of personal financial well-being . Thus, individuals should find credence and motivation to use financial knowledge in making wise financial and investment decisions for enhancing one's financial well-being (Riitsalu and Murakas, 2019). The current study therefore, hypothesize that

H2: FL significantly affects FWB among select individuals in NCR (India).

\subsection{Access to banking services (AC) and financial well-being (FWB)}

Schaner (2016) highlights positive relation between access to financial products and wellbeing of individuals. Thus, we hypothesize that

$\mathrm{H}_{3}$ : AC is positively connected with FWB among select individuals in NCR (India).

\subsection{Mediating role of access to banking services (AC)}

$\mathrm{AC}$ has got concern over the past years in both developed and developing countries. Kumari and Aluthge (2018a) point that access to banking services provides equivalent opportunities, empowers financially and socially prohibited individuals to incorporate better into the economy and secure themselves against financial stuns. Bonga and Mlambo (2016) also demonstrate that FL is significant for everybody and is connected to financial stability. This stability and quality of finance oriented products and services offer aid in development of the financial sector. Thus,

$\mathrm{H}_{4}$ : AC mediates the relation between FL and FWB among select individuals in NCR (India)

\section{OBJECTIVES}

- To analyze the association of FL level with AC of select individuals;

- To investigate the association of FL level with FWB of select individuals;

- To examine the association of AC with FWB of select individuals;

- To study AC as mediator between FL and FWB of select individuals. 


\section{PROJECTED THEORETICAL MODEL}

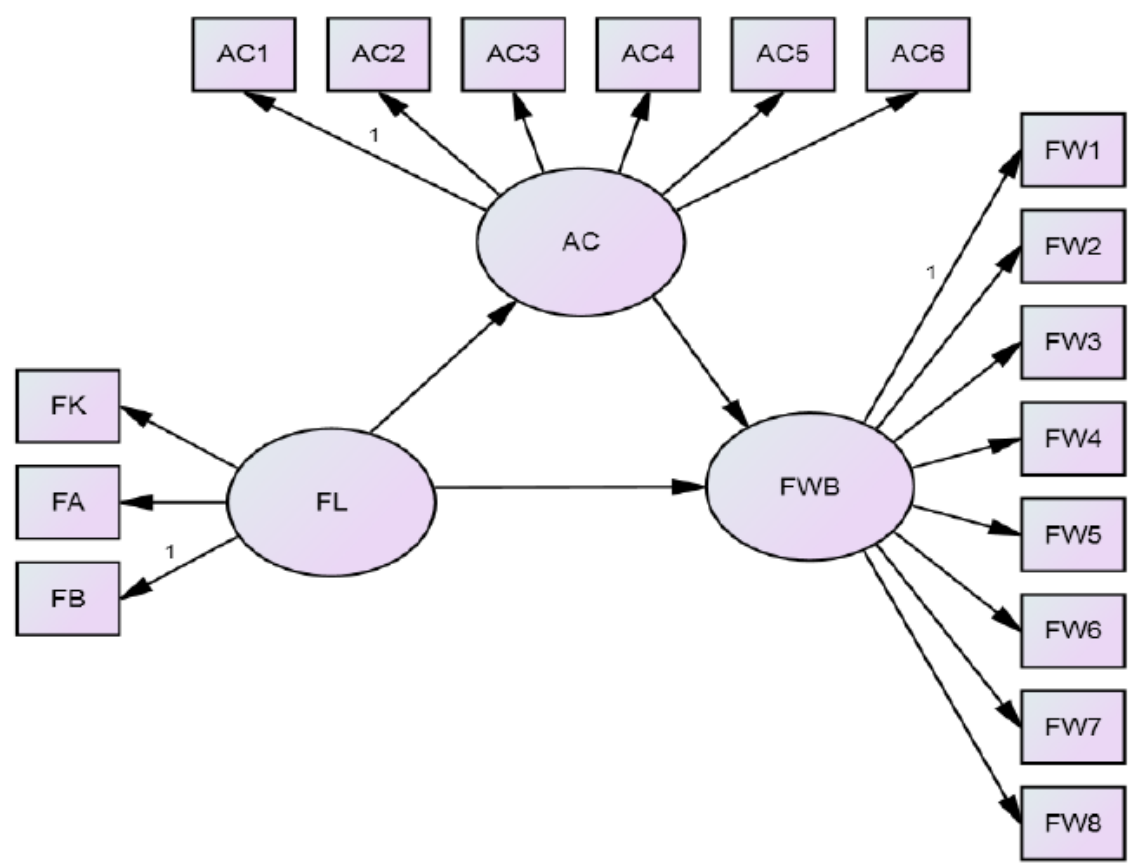

Figure 1 Projected theoretical model

\section{METHODOLOGY OF RESEARCH}

\subsection{Research design}

Mindra and Moya (2017) and Kesmodel (2018) suggest cross section research design for assessing association between variables at a given point in time.

\subsection{Population and Sample}

Target universe for the present paper include individuals of aged above 18 residing in NCR of India and sample is drawn from the same.

Questionnaires were circulated to more than 500 individuals visiting bank branches in the chosen area and approached directly. After neglecting the less responded questionnaires finally we got 476 and response rate around $95.2 \%$ which is very high.

\subsection{Sampling Procedure and Measurement of Variables}

The current study uses convenience sampling technique to carry out the research. Mohtar et al. (2014) claim convenience sampling as the best method of collecting basic information rapidly and proficiently in exploratory research.

Questionnaire involves three issues namely financial literacy, access to financial services and financial well-being. The current study adopts the dimensions suggested by Agarwalla et al. (2013); OECD (2013) and Potrich et al. (2016) to measure financial literacy.

Sarma (2010); Gupte et al. (2012) and Yorulmz (2013) work provide base for measuring access to banking services. Prawitz et al. (2006) and Consumer Financial Protection Bureau (CFPB), 2015 work provide base for measuring financial well-being. All statements use 5 point likert scale. The study findings report that Cronbach's alpha $(\alpha)$ coefficients of all the items range between $0.912,0.9090 .903,0.767$ and 0.872 for FK, FB, FA, AC and FWB respectively. 
The study uses confirmatory factor analysis to check validity of instrument. Table 1 shows the standardized loading of all the variables. All the variables had standardized loadings larger than 0.50 . To check the convergent validity, Hair et al. (2010) suggest that value should be more than 0.7 for composite reliability (CR) and more than 0.5 for average variance explained (AVE). Lastly, CR should be greater than AVE.

Table 1 Confirmatory Factor Analysis (Measurement Model)

\begin{tabular}{|c|c|c|c|c|}
\hline Construct & Variables & $\begin{array}{c}\text { Standardized } \\
\text { Loadings }\end{array}$ & $\begin{array}{c}\text { Composite } \\
\text { Reliability } \\
\text { (CR) }\end{array}$ & $\begin{array}{c}\text { Average } \\
\text { Variance } \\
\text { Explained } \\
\text { (AVE) }\end{array}$ \\
\hline \multirow{9}{*}{$\begin{array}{l}\text { Financial } \\
\text { Knowledge (FK) }\end{array}$} & $\mathrm{FK}^{1}$ & 0.81 & \multirow{9}{*}{0.886} & \multirow{9}{*}{0.567} \\
\hline & $\mathrm{FK}^{2}$ & 0.76 & & \\
\hline & $\mathrm{FK}^{3}$ & 0.77 & & \\
\hline & $\mathrm{FK}^{4}$ & 0.80 & & \\
\hline & $\mathrm{FK}^{5}$ & 0.75 & & \\
\hline & $\mathrm{FK}^{6}$ & 0.67 & & \\
\hline & $\mathrm{FK}^{7}$ & 0.62 & & \\
\hline & $\mathrm{FK}^{8}$ & 0.72 & & \\
\hline & $\mathrm{FK}^{y}$ & 0.69 & & \\
\hline \multirow{8}{*}{$\begin{array}{l}\text { Financial Attitude } \\
\text { (FA) }\end{array}$} & $\mathrm{FA}^{1}$ & 0.70 & \multirow{8}{*}{0.778} & \multirow{8}{*}{0.539} \\
\hline & $\mathrm{FA}^{2}$ & 0.85 & & \\
\hline & $\mathrm{FA}^{3}$ & 0.76 & & \\
\hline & $\mathrm{FA}^{4}$ & 0.72 & & \\
\hline & $\mathrm{FA}^{5}$ & 0.89 & & \\
\hline & $\mathrm{FA}^{6}$ & 0.74 & & \\
\hline & $\mathrm{FA}^{\top}$ & 0.70 & & \\
\hline & $\mathrm{FA}^{8}$ & 0.62 & & \\
\hline \multirow{7}{*}{$\begin{array}{l}\text { Financial } \\
\text { Behaviour (FB) }\end{array}$} & $\mathrm{FB}^{1}$ & 0.71 & \multirow{7}{*}{0.911} & \multirow{7}{*}{0.512} \\
\hline & $\mathrm{FB}^{2}$ & 0.85 & & \\
\hline & $\mathrm{FB}^{3}$ & 0.76 & & \\
\hline & $\mathrm{FB}^{4}$ & 0.72 & & \\
\hline & $\mathrm{FB}^{5}$ & 0.89 & & \\
\hline & $\mathrm{FB}^{6}$ & 0.75 & & \\
\hline & $\mathrm{FB}^{7}$ & 0.69 & & \\
\hline
\end{tabular}


Impact of Financial Literacy (FL) and Access to Banking Services (AC) on Financial Well-being (FWB): An Empirical Study

\begin{tabular}{|c|c|c|c|c|}
\hline \multirow{6}{*}{$\begin{array}{l}\text { Access to Banking } \\
\text { Services (AC) }\end{array}$} & $\mathrm{AC}^{\mathrm{I}}$ & 0.52 & \multirow{6}{*}{0.815} & \multirow{6}{*}{0.471} \\
\hline & $\mathrm{AC}^{2}$ & 0.51 & & \\
\hline & $\mathrm{AC}^{3}$ & 0.73 & & \\
\hline & $\mathrm{AC}^{A}$ & 0.75 & & \\
\hline & $\mathrm{AC}^{5}$ & 0.57 & & \\
\hline & $\mathrm{AC}^{6}$ & 0.53 & & \\
\hline \multirow{8}{*}{$\begin{array}{l}\text { Financial Well } \\
\text { Being (FWB) }\end{array}$} & $\mathrm{FW}^{1}$ & 0.51 & \multirow{8}{*}{0.895} & \multirow{8}{*}{0.549} \\
\hline & $\mathrm{FW}^{2}$ & 0.73 & & \\
\hline & $\mathrm{FW}^{3}$ & 0.69 & & \\
\hline & $\mathrm{FW}^{4}$ & 0.72 & & \\
\hline & $\mathrm{FW}^{5}$ & 0.66 & & \\
\hline & $\mathrm{FW}^{6}$ & 0.62 & & \\
\hline & $\mathrm{FW}^{7}$ & 0.71 & & \\
\hline & $\mathrm{FW}^{8}$ & 0.73 & & \\
\hline
\end{tabular}

\section{DATA ANALYSIS AND FINDINGS}

\subsection{Demographic profile of respondents}

The sample consists of 53.9\% male and $43.1 \%$ female. Most of the respondents belong to 25 35 years age group i.e. $45.83 \%$. Majority of respondents are post graduate i.e. $51.8 \%$ which show majority of respondents are literate. $70.83 \%$ of the total respondents fall in the category of service. More respondents belong to Rs. 5,00,001- Rs. 10,00,000 income group i.e. $33.07 \%$ and least belong to above Rs. 10,00,000 income group i.e. 13.55\%. Majority of the respondents are married i.e. $64.32 \%$.

\subsection{Findings}

Figure 2 demonstrates that FL $(\beta=0.41, p=0.000)$ significantly and positively influence AC of select individuals. This suggests that when individuals have an understanding of fundamental financial concepts, they can know the significance of financial services and hence results in advancement of FI. Thus, hypothesis $\mathrm{H}_{1}$ cannot be rejected. The results of the study support the findings of Grohmann (2018) \& Cole, Sampson and Zia (2009). Figure 3 shows that FL $(\beta=0.45, \mathrm{p}=0.000)$ influences FWB of select individuals. Thus, hypothesis $\mathrm{H}_{2}$ can't be rejected. The findings are in conformity with Riitsalu and Murakas (2019) \& Philippas and Avdoulas (2020) findings which show that FL results in better and informed financial decisions and an ultimately higher level of FWB. FL results in the management of day to day finance related activities i.e. budget preparation, wise investment, improved riskreturn decisions, enhanced financial wealth and ultimately better living standard. The results also reveal significant association between $\mathrm{AC}$ and FWB of the select individuals $(\beta=0.55, \mathrm{p}$ $=0.000$ ), therefore, $\mathrm{H}_{3}$ of the current study can't be rejected. 


\subsection{Testing of mediation effect}

The study fulfills the guidelines given by Baron and Kenny (1986) for testing presence of mediation effect as shown below:

(a) Effect of FL on $\mathrm{AC}(\beta=0.41, \mathrm{p}=0.000)$ is significant as shown in figure 2 .

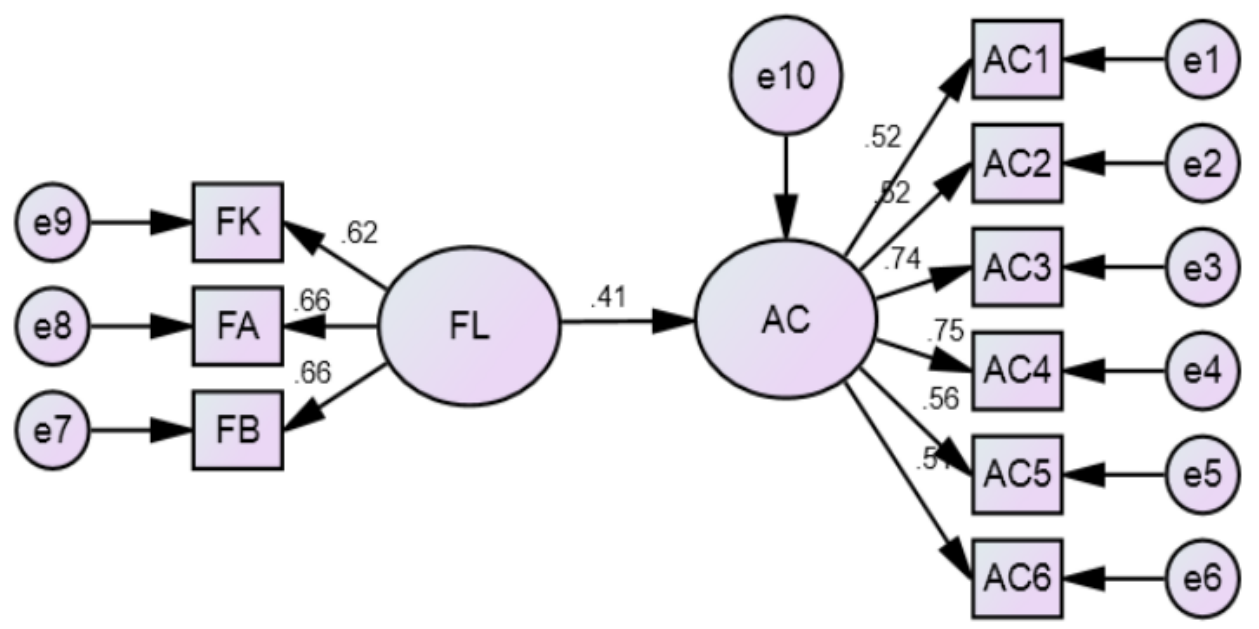

Figure 2 Impact of FL on AC

b) Effect of FL on FWB $(\beta=0.45, p=0.000)$ is significant as shown in figure 3 .

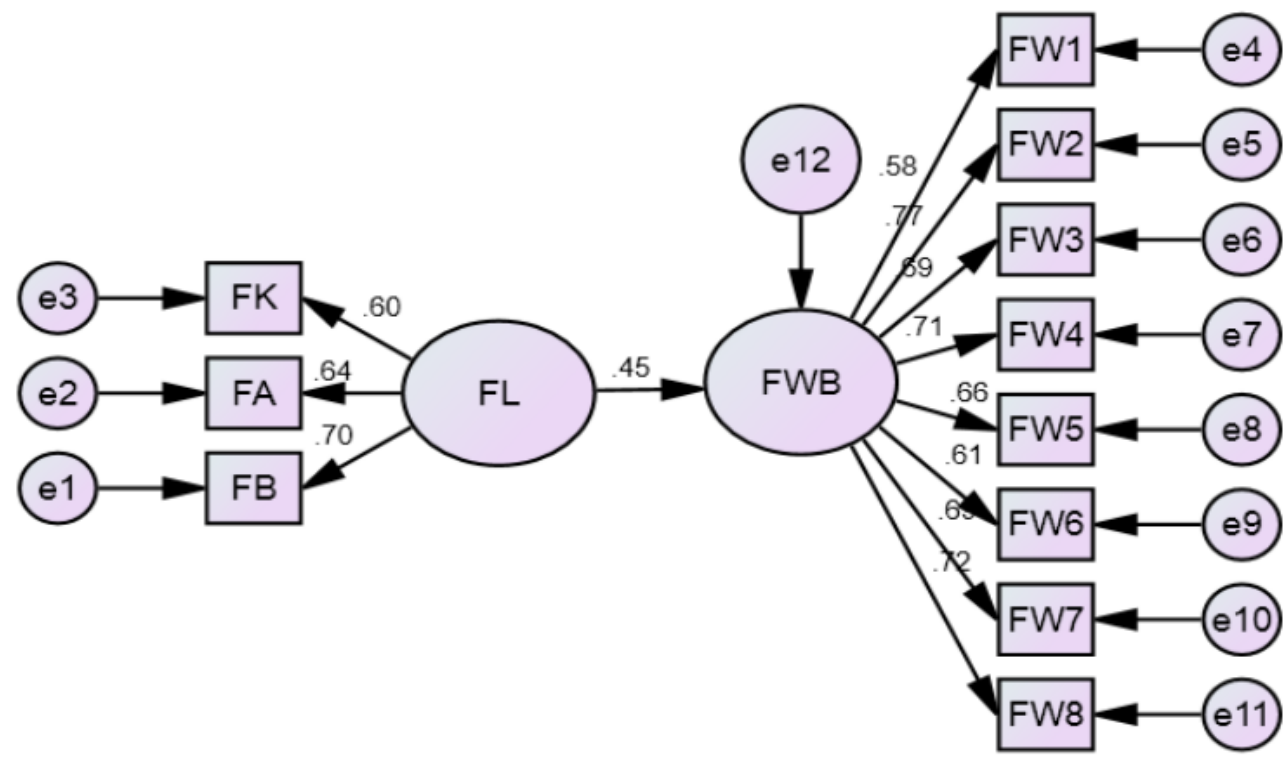

Figure 3 Impact of FL on FWB

c) It becomes clear from the figure 4 that when mediator i.e. AC is introduced into model then the relationship between FL and FWB remains significant but effect of FL on FWB got reduced i.e. $(\beta=0.31, p=.000)$. This shows AC partially mediates the relation between FL and FWB. In view of these results hypothesis $\mathrm{H}_{4}$ failed to be rejected. 


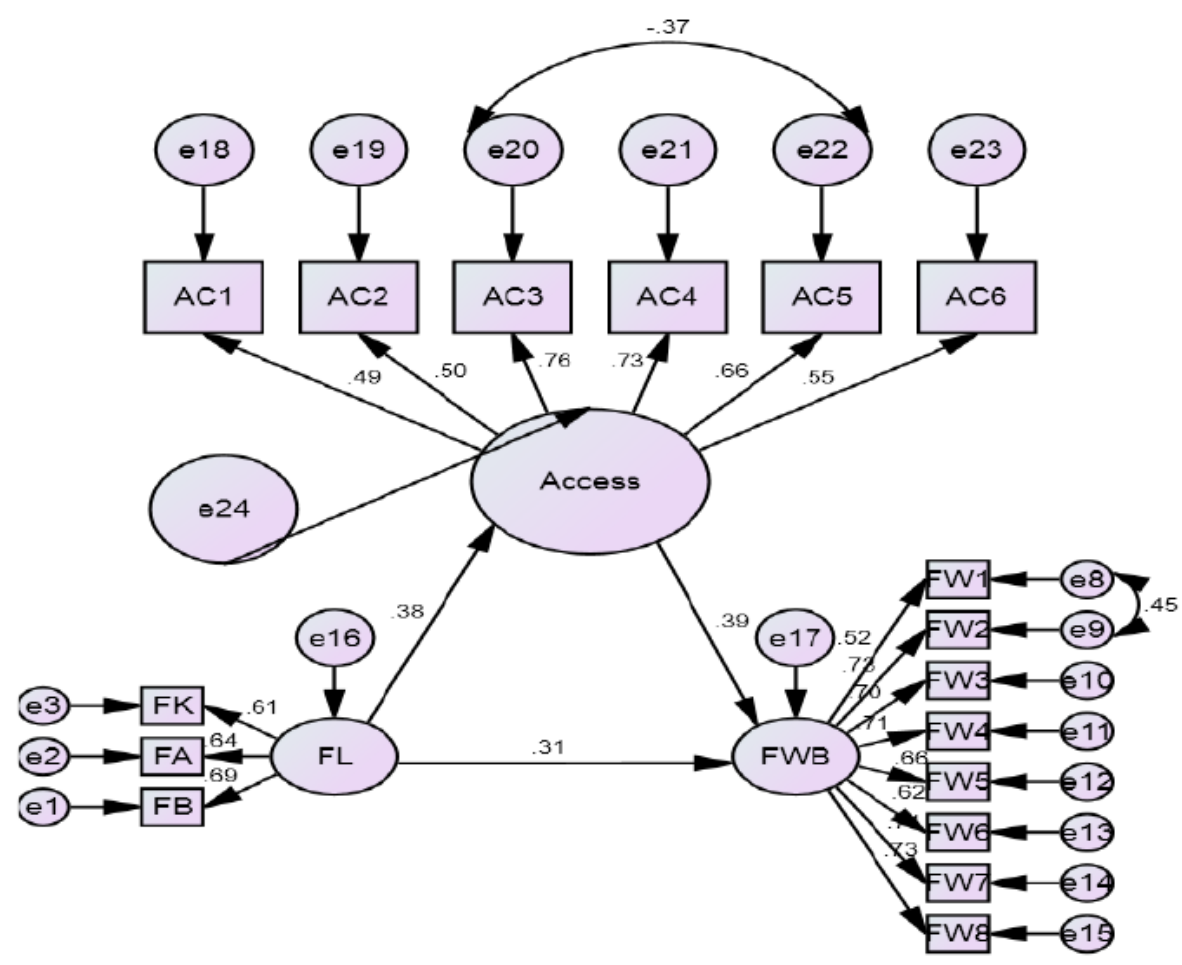

Figure 4 Impact of FL on FWB through AC

Table 2 summarizes full SEM model and the fit indices for the proposed model. The results show that the proposed model fulfills the best fitting model criteria and is used as a final model. Fitness indices GFI $=0.954$ which is more than the acceptable limit i.e. 0.90 . AGFI $=0.918$ is also more than threshold value $>0.80$. CFI $=0.946$ is also within the acceptable criteria. REMSEA value 0.052 is moderate and CMIN/df 3.778 is also acceptable. So, on the basis of indices, the model could be considered a fit and reliable model.

Table 2 Fitness of Structural Equation Model

\begin{tabular}{|c|l|l|l|l|l|}
\hline Model & CMIN/DF & \multicolumn{1}{|c|}{ GFI } & \multicolumn{1}{|c|}{ AGFI } & \multicolumn{1}{c|}{ CFI } & RMSEA \\
\hline Proposed & 3.778 & 0.954 & 0.918 & 0.946 & 0.052 \\
\hline
\end{tabular}

\section{CONCLUSION}

Most of the prior studies in the literature that has received less attention are the FL and FWB can be mediated by financial inclusion determinant i.e. AC. Present study is intended to provide empirical facts on the mediating effect of $\mathrm{AC}$ in the association between FL and FWB of the individuals dwelling in NCR of India. Findings show that FL significantly accounts for variation in AC. This supports $\mathrm{H} 1$ of the study i.e. significant effect of FL on AC of the select individuals. In addition, study shows that FL is favorably related to FWB of the select individuals, therefore, confirming $\mathrm{H} 2$ of the study. The results also demonstrate that $\mathrm{AC}$ and FWB are emphatically associated. This is in congruity with $\mathrm{H} 3$ of this study. Lastly, AC partially mediates the relation between FL and FWB is additional contribution to the study. This supports $\mathrm{H} 4$ of the study. Thus, the present study will help government and policymakers in framing national strategies and designing policies suitable for groups who lack financial 
literacy and access to banking services. Awareness programs can be conducted to make individuals aware of finance oriented products and services. This will ultimately enhance the FWB of individuals.

\section{LIMITATIONS OF THE STUDY}

The current study ignores the longitudinal design. Further, this study was carried out in the NCR of India so that results can't be generalised to other areas and countries. More so, by exploring other aspects of financial inclusion like usage of banking services, availability of banking services, etc into the research model, future research may deliver an increasingly viable model that was produced in the current study.

\section{REFERENCES}

[1] Agarwalla, S.K., Barua, S.K., Jacob, J. and Varma, J.R. (2013), "Financial literacy among working young in urban India", IIMA Working Paper No. 2013-10- 02, 1-27.

[2] Allen, F., Demirguc-Kunt, A., Klapper, L. and Peria, M. S. M. (2012), "The foundations of financial inclusion: Understanding ownership and use of formal accounts", The World Bank.

[3] Angela, A. H., Parker, A. M. and Yoong, K. J. (2009), "Defining and measuring financial literacy", RAND Labor and Population. Working Paper Series, 708. Department of Labor and the National Institute on Aging via the RAND Royal Center for Financial Decision Making.

[4] Atkinson, A. and Messy, F.A. (2012), "Assessing Financial Literacy in 12

Countries: An OECD/INFE International Pilot Exercise", Journal of Pension Economics \& Finance, Vol. 10 No. 4, pp. 657-665.

[5] Baron, R. M. and Kenny, D. A. (1986), "The moderator-mediator variable in social psychological research: Conceptual, strategic, and statistical distinction Journal of Personality and Social Psychology, Vol. 51, No. 6, pp. 1173. considerations",

[6] Bonga, W. G. and Mlambo, N. (2016), "Financial Literacy Improvement Among Women in Developing Nations: A Case for Zimbabwe", Quest Journals, Journal of Research in Business and Management, Vol. 4, No. 5, pp. 22-31.

[7] Braunstein, S. and Welch, C. (2002), "Financial literacy: An overview of practice, research, and policy”, Federal Reserve Bulletin, Vol. 88, No. 11, pp. 445- 457.

[8] Caskey, J.P. (2006), "Can Personal Financial Management Education Promote Asset Accumulation by the Poor?”, NFI Policy Briefs 2006-PB-06, Indiana State University, Scott College of Business, Networks Financial Institute.

[9] CFPB (2015), "Financial well-being: the goal of financial education", Consumer Financial Protection Bureau.

[10] Chakravarty, S. R. and Pal, R. (2013), "Financial inclusion in India: An axiomatic approach", Journal of Policy Modeling, Vol. 35, No. 5, pp. 813-837.

[11] Cochran, W. G. (1977), "Sampling techniques (3rd ed.)", New York: John Wiley \& Sons. 
Impact of Financial Literacy (FL) and Access to Banking Services (AC) on Financial Well-being (FWB): An Empirical Study

[12] Cohen, M. and Nelson, C. (2011), "Financial literacy: a step for clients towards financial inclusion", working paper, World Bank, Washington, DC.

[13] Cole, S., Sampson, T. and Zia, B. (2009), "Financial Literacy, Financial Decisions, and the Demand for Financial Services: Evidence from India and Indonesia", Harvard Business School, Working Paper 09-117.

[14] Damodaran, A. (2013), "Financial Inclusion: Issues and Challenges", AKGEC International Journal of Technology, Vol. 4, No. 2, pp. 54-59.

[15] Ghosh, S. and Vinod, D. (2017), "What constrains financial inclusion for women? Evidence from Indian micro data", World Development, Vol. 92, pp. 60- 81. https://doi.org/10.1016/j.worlddev.2016.11.011

[16] Grohmann, A. (2018), "Financial literacy and financial behavior: Evidence from the emerging Asian middle class", Pacific-Basin Finance Journal, No. 48, pp. 129-143.

[17] Gupte, R., Venkataramani, B. and Gupta. D. (2012), “Computation of financial inclusion index for India”, Procedia - Social and Behavioral Sciences, Vol. $\quad 37$, pp. 133-149.

[18] Hair JR, J. F., Black, W. C., Babin, B. J., and Anderson, R. E. (2010), "Multivariate $\quad$ Data Analysis (7th Ed.)", Upper Saddle River, NJ: Pearson Prentice Hall.

[19] Hogarth, J.M. (2006), "Financial Education and Financial Well-Being”, International Conference hosted by the Russian G8 Presidency in Cooperation with the OECD.

[20] Kesmodel, U. S. (2018), “Cross-sectional studies-what are they good for?”, Acta obstetricia et gynecologica Scandinavica, Vol. 97 No. 4, pp. 388-393.

[21] Kumari, D.A.T. and Aluthge, C. (2018a), "Financial Literacy as an Antecedent of Financial Inclusion: An Empirical Study among Rural Poor in Kurunegala District, Sri Lanka", International Research Symposium, Social Science and Humanities (IRSSSH), National Centre for Advanced Studies in Humanities and Social Sciences Sri Lanka.

[22] Lusardi, A. (2002), "Increasing Saving among the Poor: The Role of Financial Literacy", Poverty Research News, Vol. 6 No. 1.

[23] Mindra, R. and Moya, M. (2017), "Financial self-efficacy: a mediator in advancing financial inclusion", Equality, Diversity and Inclusion: An International Journal, Vol. 36 No. 2, pp. 128-149.

[24] Mohtar, N. M., Amirnordin, N. A. and Haron, H. (2014), "Ayamas food corporation Sdn. Bhd: a study on the factors of consumer behaviour towards Halal product selection", Procedia-Social and Behavioral Sciences, Vo1.21 No. 2, pp. 166-185.

[25] Nye, P. and Hillyard, C. (2013), "Personal financial behavior: The influence of quantitative literacy and material values", Numeracy, Vol. 6, No. 1, pp. 3.

[26] OECD (2013), "Financial Literacy and Financial Inclusion: Guidance, Core Questionnaire and Supplementary Questions", Retrieved from http://www.oecd.org/finance/financial education/Toolkit-to-measure-fin-lit- $\quad$ 2013.pdf

[27] Philippas, N. D. and Avdoulas, C. (2020), "Financial literacy and financial well- being among generation-Z university students: Evidence from Greece". The European Journal of Finance, Vol. 26, No. 4-5, pp. 360-381. 
[28] Potrich, A.C.G., Vieira, K.M. and Wesley Mendes-Da-Silva, W. (2016), "Development of a financial literacy model for university students", Management Research Review, Vol. 39, No. 3, pp. 356-376.

[29] Prawitz, A., Garman, E. and Sorhaindo, B. (2006). "The incharge financial distress/financial well-being scale: establishing validity and reliability". Proceedings of the 2006 Association for Financial Counseling and Planning Education, pp. 77-89.

[30] Remund, D.L. (2010), "Financial literacy explicated: the case for a clearer definition in an increasingly complex economy", The Journal of Consumer Affairs, Vol. 44 No. 2, pp. 276.

[31] Riitsalu, L. and Murakas, R. (2019), "Subjective financial knowledge, prudent behaviour and income: the predictors of financial well-being in Estonia", International Journal of Bank Marketing, Vo. 37, No. 4, pp. 934- 950.

[32] Sarma, M. (2010), "Index of Financial Inclusion”, Discussion Paper 10-05. New Delhi: Centre for International Trade and Development, School of International Studies, Jawaharlal Nehru University.

[33] Schaner, S. (2016), "The Persistent Power of Behavioral Change: Long-Run Impacts of Temporary Savings Subsidies for the Poor”, NBER Working Paper 22534. Cambridge, MA: National Bureau of Economic Research.

[34] Widdowson, D. and Hailwood, K. (2007), "Financial literacy and its role in promoting a sound financial system", Reserve Bank of New Zealand Bulletin, Vol. 70, No. 2.

[35] Yorulmz, R. (2013), "Construction of a Regional Financial Inclusion Index in Turkey", Journal of BRSA Banking and Financial Markets, Vol.7 No. 1, pp. 79-101. 